\title{
Civic Management Model: A Citizenship Management Practice
}

\author{
Emmanuelle de Verlaine Ph.D. \\ Professor, Administration Sciences Department \\ Université du Québec en Outaouais \\ Gatineau Campus
}

\begin{abstract}
Citizens expectancies toward businesses have shifted their demands to lead world transformation in a more Citizen-focus approach, jeopardizing business economic performances. Our research question is: How does management integrate these new civic expectations in practice? Our abductive methodology covers 50 case studies of businesses, non-governmental organizations, public administrations and social movements. This paper presents the three approaches discovered illustrated by 13 case studies: 1) a Citizen-Inclusion approach, 2) a Citizen-Focus approach and 3) a Citizenship approach. A comparative analysis finds correlation of these three approaches with the 3 modern management models (Technical, Social and Traditional models) for the first two approaches. This leaves the Citizenship approach revealing a whole new management model: The Civic Management Model. We discuss the organizational and managerial implications of these new management practices on business strategies, adaptabilities, innovation and contribution.
\end{abstract}

Keywords: Civic Management, Innovation, Civic-Inclusion, Civic-Focus, Citizenship, Environmental and Social Responsibilities, Actor-Network

\section{Introduction}

Modern management field, is known to be the art of an organized craft and a set of professional methods to lead organizations to deliver goods and services in a complex economic environment creating economic wealth. Over the last two decades, organizations have increasingly focused and been pressured to address environmental and social responsibilities in order to adapt themselves into a changing social, ethical and political environment (Caillé 2003, Favreau et al. 2004, Oeyono et al 2011). These changes manifest themselves through citizens voicing their requirements as civic expectancies sometimes become new formal rules and regulations, new norms and ethical practices (Aguiton 2003, Bourguimont 2005). A successful management practice integrating these civic expectancies are measured by increased market share and shareholder value growth because conforming to civic expectancies create trust, loyalty and ultimately a bound between stakeholders, communities and the organization (Brammer et al. 2012, Clarkson et al 2011).

These civic expectancies have changed some organizational processes and even strategies and business models to adapt to this changing environment. Not only are they playing an economic role, but communities expect them to take significant roleinto global ecological, human and social issues. It doesn't mean that economic growth is not important, but in some cases, alternative aims from economic growth have emerged to create better human living conditions as well as climate and environment restoration and renewal. We question if these civic expectations are becoming so intensive that they may need more than marginal adaptation of management practices to lead organizations.

Our research question: How does management integrate these new civic expectations practice?

\section{Research methodology}

Our abductive research methodology is based on business case studies as well as non-governmental, public administration organizations and social movements from the activist's official websites.

The sample of 50 cases gathered from 2013 to 2020 was documented with official documents obtained from the organizations' official websites. The collected and analyzed data include Annual Financial Reports, historical documents, formal organizational culture documents, business model, and documented mission statements, vision, strategy, formal value statements and Charters including, when possible, case study reports and analysis from other researchers.

The abductive analysis process was done in five phases:

1. Categorizing management practices used to address civic expectations into management approaches.

2. Those approaches are correlated with management models and practices known in management field (Déry 2010). 
3. When the practices deviated significantly from known management literature, it is submitted to a comparative analysis to sub-categorize the management practices differences and their impact on organizational performances. 4. Once these new sub-categories are conceptually consolidated, it is compared to the Boltanski and Thévenot (1991) professional practices classification to identify the nature of this new management approach

5. Finally, once the professional ethos classification is identified, an iterative analytical process is engaged to validate if those alternative practices confirm an emerging new management model.

\section{Literature on managements and practices}

The management field has conceptualized management models based on documented management practices. Through an iterative process, the intellectual and scientific community integrated new dimensions to the management models, based on new transdisciplinary research on organizational behaviors, organizational theories and management new knowledge (on strategy, finance, marketing, governance, operations and so on) whish in return were integrated in organizational management practices (Déry 2010). The field is therefore built with both Management Models and related normative management practices based on empirical data. This literature review presents a synthesis on currently known management models and practices.

\subsection{Management Models}

Management literature presents three management models: Traditional, Technical and Social Management Models (Déry 2010). Originally, the management literature positions the Traditional Management as the precursor of the technical and social management models, at the early stages of industrial revolution at the end of the XIX ${ }^{\text {th }}$ and beginning of the $\mathrm{XX}^{\text {th }}$ Centuries (Déry 2010). It is focusing on a community of practice, much like the preindustrial craftsmanship. This particular management model is focused on the quality of the craft in the business operations, and therefore believes in a traditional social hierarchy promoting mentorship from the best experienced workers training the apprentice into the craftsman community of best practices. Its main concern is to maintain harmony is this community to ensure its best working relations within the chain workers along with the customers satisfaction of the best results. Any managerial decisions should be understood as a contributing force to maintain such a craftsman bounded community to sustain best practices. This kind of management model allows businesses to insure the public and the market of the best practices, which is certainly an important asset in health care, pharmaceutical products, food industry, law practices and so on.

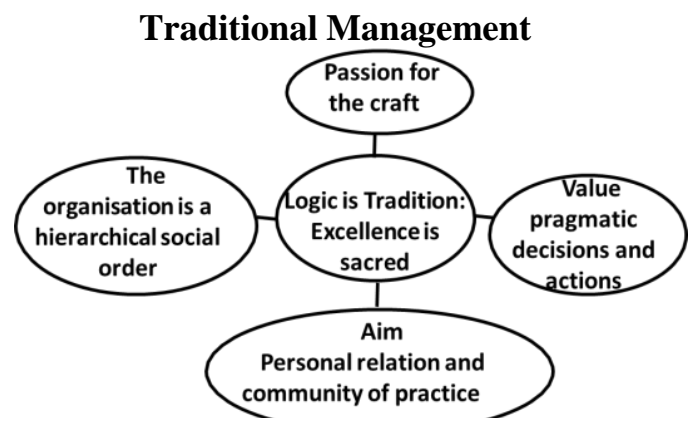

It is in 1908 Henry Ford, 1910, with Frederick Taylor, Henri Fayol in 1920 that the early signs of the Technical Management emerged (Déry 2010). Respectively entrepreneurs, engineering consultant and military officer, these founders of the Technical Management all share a passion for technology both in terms of hardware as in methodology to guide work protocols. Rationality, objectivity, and most of all, scientific knowledge was early on understood as the foundations to continuously improve business performance in terms of productivity, efficiency, effectiveness and operating cost control. All decisions should therefore be based on facts and scientific knowledge to ensure ongoing innovations supporting economic growth. Finally, this new form of self-determination of humankind through scientific knowledge applied to managing the production workers and division of labor, would be in the interest of all since Ford implemented a policy of sufficient wages increase to allow his workers to buy the very car they manufactured. This was the beginning of wealth creation for all through economic productivity that Technical Management Model of practice could implement. 


\section{Technical Management}

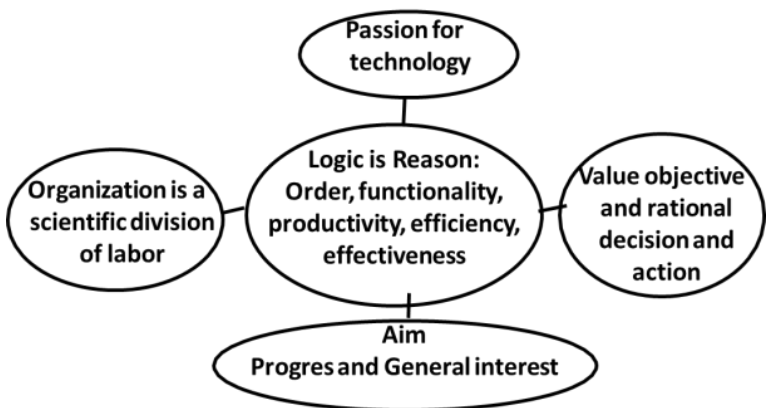

In 1929, with Milton Mayo research initiated the Social Management Model (Déry 2010). Inspired by the Technical Management Model, Elton Mayo pursued research to develop the best ergonomic workstations to sustain productivity in the chain of production. At the end of the research, the results were inconclusive. Mayo looked back on the research methodology and figured-out that the actual incentive for productivity improvements were not ergonomic adjustments as such, but rather the fact that employees contributed in the discussions and the managerial practice to re-arrange their work stations. Since this experiment, human and social sciences became the pillar to reveal new human and social dynamics and dimensions unforeseen by the Technical Management Model. The Social Management Model values debating ideas, perspectives and interests in a collaborative manner with the stakeholders themselves to create value in more complex and adaptive managerial decisions and actions. The organization is view as a working togetherness environment where trust toward management is key to ensure real involvements. Management practitioners have to be therefore trustworthy through their ethics, integrity and ability to mobilize the workforce as the primary stakeholders, followed by customers, suppliers, business partners and any other relevant stakeholders to the business performances.

\section{Social Management}

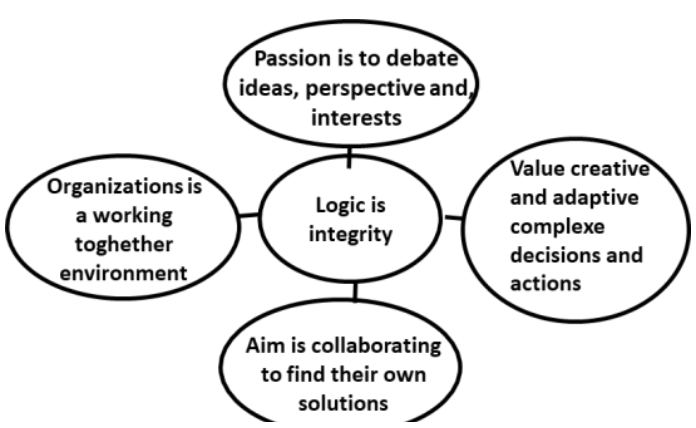

The three management models have evolved all along throughout the $X^{\text {th }}$ Century (Déry 2010). They co-practice in most organizations as an ecosystem where all three models aim at leading the business to economic performances through adaptation to the changing environment and construct a solid position in the markets.

These three models recapture the essence of their related practices. Boltanski and Thévenot (1991) extensive research have find 6 main professional practices categorized into ethos identification: 1) Communal ethos (find in Traditional and Civic practices); 2) the Individuation ethos (find in Innovative and Prestigious seeking practices); 3) Technical ethos (find in Professional and Merchant practices).

Professionnal Practices Typology

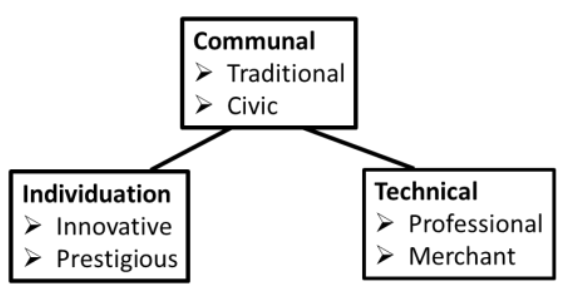

(Boltanski and Thévenot 1991)

In correlation we can see the Traditional Management Model exhibit a Communal ethos and approach in its practice. 
The Technical Management Model reveals both professional and merchant perspectives on the management practice. And finally, the Social Management Model position itself as both communal and individuation ethos and practices.

\subsection{Management practices}

All three model are based on a framework based on Fayol method which is: PODC (Planning, Organizing, Directing, Coordinating/Controlling) practices founded by the Technical Management Model in 1910 with Fayol (Déry 2010). Each model of management approach these practices with a different angle while ensuring a primary focus on economic performances. Over time, these PODC management practices have been improved integrating social sciences knowledge into developing information and knowledge management, innovations management, decision theories and practices to sustain strategic and economic performances (Déry 2010).We are recognizing these Informing, Comprehending, Innovating and Deciding (ICID practices as complementary to the PODC normative practices

Given, as related earlier, an ever-increasing human right, social justice and ecological expectations from markets, government regulations and communities, we question how do these management models adapt or integrate these new challenges given a new global integrated environment.

\section{Results}

The results show a first categorization of 3 civic management approaches to deal with civic expectations: 1) the Civic-Inclusion approach, 2) the Civic-Focus approach and 3) the Citizenship approach. To illustrate these approaches, we have chosen 10 business cases, 2 non-governmental organizations and 1 social movement.

\begin{tabular}{|c|c|c|c|}
\hline & $\begin{array}{l}\text { Civic-Inclusion } \\
\text { approach }\end{array}$ & $\begin{array}{l}\text { Civic-Focus } \\
\text { approach }\end{array}$ & $\begin{array}{l}\text { Citizenship } \\
\text { approach }\end{array}$ \\
\hline $\begin{array}{l}\text { Management } \\
\text { model }\end{array}$ & $\begin{array}{l}\text { Technical Management } \\
\text { model }\end{array}$ & $\begin{array}{l}\text { Social and Traditionnal } \\
\text { Management models }\end{array}$ & $\begin{array}{l}\text { Civic Management } \\
\text { model }\end{array}$ \\
\hline $\begin{array}{l}\text { Management } \\
\text { practices }\end{array}$ & $\begin{array}{l}\text { Primarely PODC } \\
\text { practices supported by } \\
\text { ICID practices }\end{array}$ & $\begin{array}{l}\text { Primarely PODC } \\
\text { practices supported by } \\
\text { ICID practices }\end{array}$ & $\begin{array}{l}\text { Primarely ICID } \\
\text { practices supported by } \\
\text { PODC practices }\end{array}$ \\
\hline $\begin{array}{l}\text { Case study } \\
\text { examples }\end{array}$ & $\begin{array}{l}\text { 1. Coka-Cola } \\
\text { 2. General Motor } \\
\text { 3. Nasdaq } \\
\text { 4. TMX Ltd } \\
\text { 5. Ernst \& Young }\end{array}$ & $\begin{array}{l}\text { 6. Facebook } \\
\text { 7. Harley-Davidson }\end{array}$ & $\begin{array}{l}\text { 8. Google (Alphabet) } \\
\text { 9. SEMCO } \\
\text { 10. Ikea } \\
\text { 11. Greenpeace } \\
\text { 12. United Nations } \\
\text { 13. Global Social Movement }\end{array}$ \\
\hline
\end{tabular}

\subsection{The Civic-Inclusion approach}

This civic-focus approach is used to include civic considerations into mainly for product innovation and operational management practices.

1. Coca-Cola: develops a more ecological manufacturing process with recycling material (Coca-Cola 2020, 2019)

2. General Motors: innovates in green energy motors and ecological manufacturing processes (GM 2020)

3. NASDAQ: Adopts a more inclusive human resources policy and informs businesses on environmental rules and regulations (NASDAQ 2020a, 2020b)

4. TMX Ltd: Adopts a more inclusive human resources policy and informs businesses on environmental rules and regulations (TMX 2020a, 2020b)

5. Ernst \& Young: Adopts a more inclusive human resources policy, informs businesses on environment rules and regulations and on law suits risks for non-regulation compliances (Ernst\&Young 2020a, 2020b)

These business civic practices are conforming to a Technical Management Model by integrating new norms to respond to new market demands (both consumers and workers) and public policies concerning environmental issues. In fact, they are inclined to adopt the proven international certifications on environment management (ISO 14001) concerning operational processes, Quality Management (ISO 9000) on product developments, and, are invited to adopt the Social responsibility guideline (ISO 26000) on social and environmental responsibilities which offers a method to manage business stakeholders (Lecomteand al. 2012). These international norms ensure credibility and minimal best-known practices on some civic issues that shareholders and financial markets would be willing to consider good citizenship practices. 
This Civic-Inclusion approach brings a contemporary management practice without disturbing the culture, corporate strategy and a profound focus on financial performances of these businesses. The normative PODC practices can marginally include ecological considerations in the product development, operational processes and human resources policy. Other than if they adopt the ISO certifications, this approach would go unnoticed in terms of strategy, culture and managerial practices. In fact, these certifications propose to use innovative technology to increase business efficiency and therefore its economic performances as the primary objective. In other words, it complies to the Technical Management Model.In fact, amongst the businesses presented in this approach, Ernst \& Young, Nasdaq and TMX offer their clients (which are all businesses) support to learn how to report compliances disclosures on rules and regulations (Sarbanes-Oxley Compliance on regulatory disclosure) (Ernst \&Young 2020a; NASDAQ 2020b; TMX 2020b).

Their mission is to educate entrepreneurs and managers to master these public policy laws, just like any other rules and regulations they have to comply to like accounting, health and safety workplace conditions, human resources management regulated requirements and so on. These management practices may add to the bureaucratic load of paper work, but it doesn't change the neoliberalism economic growth management paradigm. Not surprisingly, we find that the Civic-Inclusion approach is the most common approach adopted in businesses, public administrations and non-governmental organizations (Loncarand al. 2019).

\subsection{The Civic-focus approach}

This Civic-Focus approach is used in businesses focusing on citizens' needs for more agility in product and services by working closer with their immediate related communities as stakeholders.

We find that in most cases Civic-Focus approach to manage civic expectations imply to include stakeholders in their strategic performances. Unfortunately, including the stakeholders' interests makes the businesses strategically vulnerable to political influences. The two best examples of that vulnerability are Facebook and Harley-Davidson.

1. Facebook: The business model is based onsocial bounding amongst citizens (Facebook 2020a, 2020b)

2. Harley-Davidson: Stakeholder management approach for employees, riders, environmentalists to improve on innovative and production performances and client loyalty (Harley-Davidson 2020)

Facebook is facing regular public criticism about its ability to deal with :1) fake accounts, 2 cyber-attacks and even 3) the lack responsiveness on malicious content.

For each of these civic critics, the company had to face:

1. In April 2018, American Senate Commission to investigate a potential 2016 presidential criminal manipulation through fake accounts (Newton 2018);

2. In June 2018, the Senate Commission investigated privacy protection after a cyber-attack on Facebook (Editorial-Reuter 2018, Laslo 2019);

3. In September 2019, the company had to face the U.S. Senate in 2019 and is facing, in 2020, a customers' boycott campaign for its lack of reaction on human right threats threatening social peace (Binder 2019, Isaac and Hsu 2020).

Harley-Davidson, on the other hand, had to abandon the strategic decision to move a production line to Thailand. This strategic sound decision aimed to avoid exportation tax and fees against American products (Moghadasi 2018). Despite the company's long stakeholder's management experience, it did not prepare the company to deal with the president Donald Trumps' involvement in 2018 to launch a customer boycott. The presidents' involvement in a few tweets became the major constraint on Harley-Davidson ability to transfer its centralized operations overseas.

In both of these case studies, we can see that their Civic-Focus approach implies a bigger skin-in-the-game implication for the organizations toward not only their employees, but also to their stakeholder communities. The Social Management Model approach to deal with civic issues, embedded in their business model or their market positioning, makes them vulnerable to unforeseeable external political agendas (Schaefer 2004). They have to adapt instantly in order to save their stakeholders and their shareholders.

We may however point out that Harley-Davidson showed a quicker response than Facebook to these external political influences. It appears that the Traditional Management Model they practice since the 1990s, creates a stronger bound for the board of directors to assess the political threat in their community. This community bounding allows the top leaders to vividly experience the threat allowing them to present a quick and sound decision to answer to a civic expectation.

Facebook may be strong on the Social Management Model, but seems to lacks on Traditional Management Model which maintains social distancing between the board of director and their stakeholders (Isaac et al 2020). Their Civic-Focus approach is managed as a methodology to develop their products and services, but not to sustain a community bound. 
The two case studies allow us to see how both businesses maintain a PODC management practices supported by the ICID management practices. In other words, their strategy, operations and adaptability given through the ICID practices are functioning in the realm of the Technical Management Model.

Just like the Citizen-Inclusion approach, including stakeholders' interests doesn't change the overall management practices. Strategic and operational decisions are still being made primarily to keep financial growth stable to meet shareholders expectations. They become vulnerable when their stakeholders don't agree with their management practices. We have found that this Civic-Focus approach is marginal in the case studies. It was, however found in earlier stages of management practices evolution in some businesses like Google and SEMCO, in the years 2000, until they adopted a Citizenship approach since the last 10 years (Alphabet 2020a; SEMCO 2020a, 2020b, 2020c).

\subsection{The Citizenship approach}

There third category of management practices over civic expectancies is the Citizenship approach. This management practice embraces a citizenship role into the business model, operations and contribution.

1. Google (Alphabet Inc): The business model has evolved from an internet information search technology in 1998, into a catalyst for alter-technologies to create a better world both socially and ecologically. The operations are done in a complex networking environment with partners and stakeholders to innovate. This is all done in order to contribute in creating a healthier planet, restoring biodiversity and leveraging human development (Alphabet 2020a, 2020b).

2. SEMCO: The business model has evolved over the last two decades to become a catalyst of networking to develop Brazil. The company operate as a catalyst for Brazil expansion. In other words, given an engaged role to their employees turned the company's business model into a Citizenship strategic management practice to create a web of technological and financial equal joint-venture between SEMCO and any other business partner willing to develop Brazil. SEMCO has therefore pushed the inclusion of their stakeholders in their practice to become an organizational citizen contributing in developing Brazil in all aspects including technological innovation, entrepreneurial dynamism, social and human development all in an ecological perspective (SEMCO 2020a, 2020b, 2020c).

3. IKEA: The business model has evolved from creating furniture into becoming a catalyst member of a network of business partners and non-governmental organizations "to create a better everyday life for many people". The company operates with a network of activist partners to protect biodiversity, forests, coffee and cotton culture, animal wellbeing, responsible farming, global working conditions, fighting child labor, women poverty, human rights. IKEA therefore contributes in creating a better life in a healthier planet (IKEA 2020, KPMG 2019)

To validate this Citizenship approach into a Civic Management Model in correlation to Boltaski and Thévenot (1991) typology, we are presenting three case studies of validation, which are Greenpeace, United Nations and Global Social Movement.

4. Greenpeace: This international non-governmental organizations' Business model is to offer citizens, an opportunity to change and revive the planet ecosystem. Greenpeace operates by empowering and engaging citizens around civic issues: Energy, Nature and People. It contributes by promoting awareness, knowledge, education and activism into changing the world and the planet, all made possible through public donations (Greenpeace 2020a, 2020b, 2020c).

5. United Nations: This international non-governmental organizations' business model is a network of countries and organizations to secure world peace and sustain human development around the world. Founded through country membership fees, the United Nations operates by collaborating with all stakeholders in creating knowledge, guidelines and international policies and alliances to enable informed actions and intervention (Reinicke et al. 2000). It contributes in sustaining world peace, human development and social stability, justice and equality (U.N. 2020a, 2020b).

6. Global Social Movement: This international non-organizational social movements' business model is to create scientific knowledge and intellectual understanding of the current neoliberal world order while enabling alternative solutions and innovations. It operates through scientific and intellectual publications, organized campaigns and democratic demonstrations, but also through a network of engaged activism in financial shareholders' assembly, consumers' boycott and alternative choice, through activist entrepreneurial start up initiatives including social financing and so on (Manos et al. 2016). Since 1995, this Global Social Movement contributes by integrating civic issues, concerns and need into collaborative education and intervention to restore a healthy planet, develop human development, equality and social justice (Lopes 2012, Massiah 2003, Matouk 2005). 


\section{Citizenship approach}

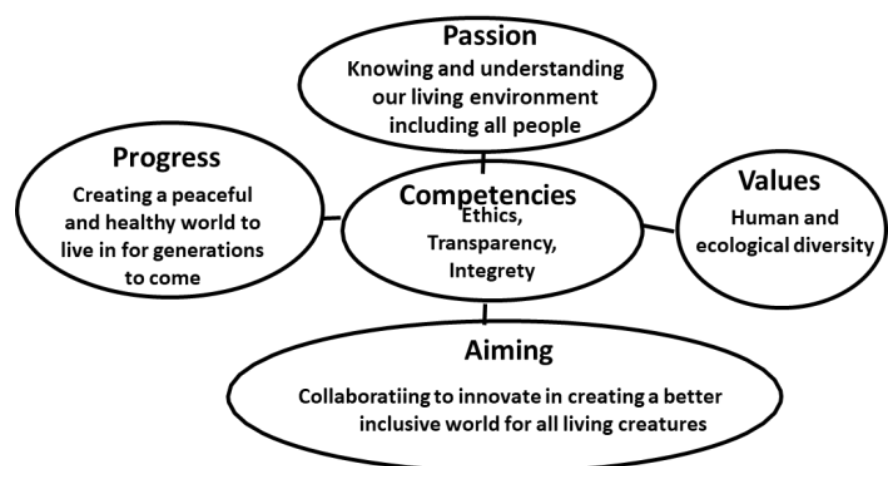

The iterative analysis of the Citizenship approach to manage civic expectancies concludes to a significantly distinct managerial approach. Moreover, all of the 6 case studies, including a non-organization, are operating in a network of partners and collaborators (Sommerfeldt et al 2017) In fact, they all operate under an Actor-Network approach to partner in their contribution (Aka 2019, Callon 2001).

As Kullak et al. (2020) studied, business models leveraging networks allows them to contribute to create a better world, taking their specific competencies as a leverage to restore our planets' health and leverage human wellbeing around the world (Scemama et al. 2019, Schaefer 2004).

\section{Civic Management model}

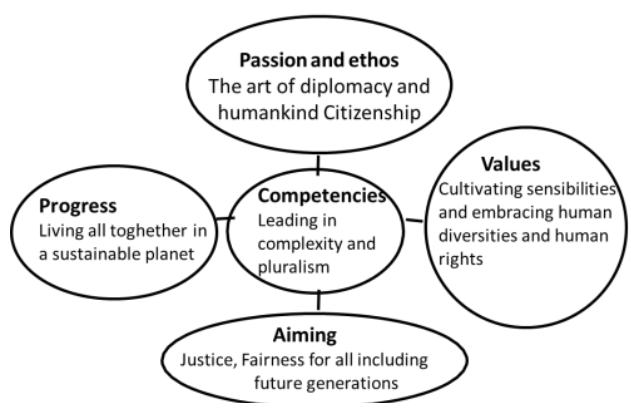

As a result of this concluding analysis, this Citizenship approach to manage civic expectancies presents all characteristics of a new management model: The Civic Management. Its practice is in accordance to the Boltanski and Thévenot (1991) professional typology of ethos and practices. From all of the cases studies that fall into this category exhibit a primary ICID practice of their contributing mission in the world, supported by the PODC managerial practices to implement this contribution.

\section{Discussion}

This long-term research, from 2013 to 2020, has the advantage of witnessing a rapid evolving new management model which embraces systemic complexity with an ease that the modern organizationally based management models have a hard time to lead. It appears that embracing the civic expectancies instead of adapting to them, even by including stakeholders in the discussion creates a highly adaptable, strategic, innovative global contribution. Even though these managerial practices have been intensively emerging over the last decade, it appears that their impact is so successful that they may become indispensable to the managerial ecosystem as a new social practice.

\section{References}

Aguiton, C. (2003). Où va le mouvement altermondialisation? : et autres questions pour comprendre son histoire, ses débats, ses stratégies, ses divergences. Paris: La Découverte.

Aka, K. G. (2019). Actor-network theory to understand, track and succeed in a sustainable innovation development process. Journal of Cleaner Production, 225, 524-540. Retrieved from http://www.sciencedirect.com/science/article/pii/S0959652619310674

Alphabet. (2020a). Alphabet: Annual Report for the fiscal yearendedDecember 31, 2019. GOOG 10-K 2019. Delaware, USA.

Alphabet. (2020b). Alphabet. G is for Google. Retrievedfrom https://abc.xyz/

Binder, M. (2019). U.S. Senetors grill Facebook, Google and Twitter on extremist content. Retrievedfrom https://mashable.com/article/facebook-google-twitter-extremism-senate-hearing/

Boltanski, L., \& Thévenot, L. (1991). De la justification. Les économies de la grandeur. Paris: Gallimard.

Bourguinat, H. (2005). Altermondialisation: un autre monde est-il possible? Problèmes économiques(2875), 30-35. 
Brammer, S., Jackson, G., \& Matten, D. (2012). Corporate Social Responsibility and Institutional Theory: New Perspectives on PrivateGovernance. FreieUniversitaet Berlin on December, 10, 3-28.

Caillé, A. (2003). Présentation. Revue du MAUSS, 21(1), 5.

Callon, M. (2001). Actor Network Theory. In N. J. Smelser\& P. B. Baltes (Eds.), International Encyclopedia of the Social \&Behavioral Sciences (pp. 62-66). Oxford: Pergamon.

Clarkson, P. M., Overell, M. B., \& Chapple, L. (2011). EnvironmentalReporting and its Relation to CorporateEnvironmental Performance. Abacus, 47(1), 27-60.

Coca-Cola. (2020). The Coca-Cola Compagny-Investors. Retrievedfrom https://investors.coca-colacompany.com/

Déry, R. (2010). Les perspectives de management. Montréal: Éditions JFD.

Editorial-Reuters. (2018). US senetorsdemandanswersfrom Facebook and Mark Zuckerberg after data sharing report. Retrievedfrom https://www.cnbc.com/2018/06/05/us-senators-demand-answers-from-facebookand-mark-zuckerberg.html

Ernst\&Young. (2020a). Global review 2019. Retrievedfrom https://www.ey.com/en_gl/global-review/2019

Ernst\&Young. (2020b). Building a betterworking world. Retrievedfrom https://www.ey.com/en_gl

Facebook. (2020a). Facebook. Investor Relations. Retrievedfrom https://investor.fb.com/home/default.aspx

Facebook. (2020b). Facebook. Annual Report Pursuant to section 13 or 15(d) of the Securities Exchange Act of 1934. California: Facebook.

Favreau, L., Larose, G. r., \&Fall, A. S. (2004). Altermondialisation, économie et coopération internationale . Sainte-Foy: Presses de l'Université du Québec.

GM. (2020). General Motors-Investors. Retrievedfrom https://investor.gm.com/

Greenpeace. (2020a). Our History. Retrievedfrom https://wayback.archive-it.org/9650/20191001185623/http://livebackup-greenpeace-org-uk.pantheonsite.io/about/impact/history/embed/

Greenpeace. (2020b). Whatwe do. Retrievedfrom https://www.greenpeace.org/international/explore/

Greenpeace. (2020c). There are lots of ways to get involved. Retrieved from https://www.greenpeace.org/international/act/

Harley-Davidson. (2020). Investors relations. Retrievedfrom https://investor.harley-davidson.com/

IKEA. (2020). IKEA About Us. Retrievedfrom https://newsroom.inter.ikea.com/about-us

Isaac, M., \& Hsu, T. (2020). Facebook Fails to AppeaseOrganizers of Ad Boycott. Retrievedfrom https://www.nytimes.com/2020/07/07/technology/facebook-ad-boycott-civil-rights.html

KPMG. (2019). Inter IKEA Holding B.V. Annual Report FY19: IKEA Holding.

Kullak, F. S., Baker, J. J., \&Woratschek, H. (2020). Enhancing value creation in social purposeorganizations: Business modelsthatleverage networks. Journal of Business Research. Retrieved from http://www.sciencedirect.com/science/article/pii/S0148296320300813

Laslo, M. (2019). Congress Is Pissed at Facebook and the FTC. Retrieved from https://www.wired.com/story/congress-pissed-facebook-ftc/

Lecomte, S. v., \&Adary, A. 1. (2012). L'ISO 26000 en pratique : faire de la responsabilité sociétale un levier de performance pour l'entreprise. Paris: Dunod.

Loncar, D., Paunkovic, J., Jovanovic, V., \&Krstic, V. (2019). Environmental and social resposibility of companies cross EU countries-Panel data analysis. Science of the Total Environment(657), 287-296.

Lončar, D., Paunković, J., Jovanović, V., \&Krstić, V. (2019). Environmental and social responsibility of companies cross EU countries - Panel data analysis. Science of the Total Environment, 657, 287-296.

Lopes, C. (2012). EconomicGrowth and Inequality: The New Post-Washington Consensus. RCCS AnnualReview, 4(4), 69-85. Retrievedfrom http://journals.openedition.org/rccsar/426

Manos, R., \&Drori, I. (2016). Corporateresponsibility: social action, institutions and governance [244 pages].

Massiah, G. (2003). Le mouvement citoyen mondial. [World Citizen Move]. Revue du MAUSS, 21(1), 23-31.

Matouk, J. (2005). Mondialisation altermondialisation. Toulouse: Éditions Milan.

Meyer-Bisch, P. (2012). Clarifier et développer les caractéristiques de l'organisation civile. [Clarifying and Developing the Characteristics of Civil Organization]. MondesenDeveloppement, 159(3), 105-116.

Moghadasi, M. (2018). Strategic Analysis: A Case Study of Harley-Davidson. Retrieved from https://www.researchgate.net/publication/333893498_Strategic_Analysis_A_Case_Study_of_HarleyDavison

Nasdaq. (2020a). Nasdaq Inc. Annual Report Pursuant to Section 13 or 15(d) of the Securities Exchange Act of 1934. New York: Nasdaq.

Nasdaq. (2020b). Nasdaq-Investor Relations. Retrieved from http://ir.nasdaq.com/financials/annual-reports

Newton, C. (2018). The 5 biggest take ways from Mark Zuckerberg'sappearancebefore the Senate. Retrievedfrom https://www.theverge.com/2018/4/10/17222444/mark-zuckerberg-senate-hearing-highlights-cambridgeanalytica

Oeyono, J., Samy, M., \& Bampton, R. (2011). An examination of corporate social responsibility and financial performance. A study of the top 50 Indonesianlisted corporations. Journal of Global Responsability, 2(1), 100-112. 
Reinicke, W. H., Deng, F., Witte, J. M., \& International Development Research, C. (2000). Choix cruciaux : les Nations Unies, les réseaux et l'avenir de la gouvernance mondiale [1 online resource (xxii, 143 pages)].

Scemama, P., \& Levrel, H. (2019). Influence of the Organization of Actors in the Ecological Outcomes of Investment in Restoration of Biodiversity. Ecological Economics, 157, 71-79. Retrieved from http://www.sciencedirect.com/science/article/pii/S0921800918308061

Schaefer, A. (2004). Corporate sustainability - integrating environmental and social concerns? Corporate Social Responsibility and Environmental Management, 11(4), 179-187.

SEMCO. (2020a). Company History. Retrievedfrom http://www.semco.com.br/en/about-us/

SEMCO. (2020b). Systems Engineering \& Management Company. Retrieved from https://www.semco.com/

SEMCO. (2020c). SEMCO Partners. Company History. Retrieved from http://www.semco.com.br/en/about-us/

Sommerfeldt, E. J., \& Yang, A. (2017). Relationship networks as strategic issues management: An issue-stage framework of social movement organization network strategies. Public Relations Review, 43(4), 829-839. Retrieved from http://www.sciencedirect.com/science/article/pii/S0363811116304933

Steen, J. (2010). Actor-network theory and the dilemma of the resource concept in strategic management. Scandinavian Journal of Management, 26(3), 324-331. Retrieved from http://www.sciencedirect.com/science/article/pii/S0956522110000473

TMX. (2020a). TMX Group Limited. 2019 Annual Report. Toronto: TMX Group Limited.

TMX. (2020b). TMX. Investor Relations. Retrievedfrom https://www.tmx.com/investor-relations

U.N. (2020a). About Us. Council Economic and Social Retrieved from https://www.un.org/ecosoc/en/about-us

U.N. (2020b). History of the Unites Nations. Retrieved from https://www.un.org/en/sections/history/history-unitednations/index.html 